\title{
Effect of Milk and Hydro-priming on Seed Germination Characteristics of Bitter Gourd (Momordica charantia L.)
}

\author{
Md. Sadiqur Rahman ${ }^{1, a}$, Istiak Ahmed ${ }^{1, \mathrm{~b}}$, Suman Biswas ${ }^{1, \mathrm{c}}$, Monjur Morshed ${ }^{2, d, *}$, Parimal Chandra Sarker ${ }^{1, \mathrm{e}}$, \\ Md. Arafat Hossain ${ }^{1, f}$, Maria Islam ${ }^{1, g}$, Taslima Jahan ${ }^{1, h}$, Apurba Kanti Choudhury ${ }^{1, i}$
}

${ }^{I}$ Bangladesh Agricultural Research Institute (BARI), Joydebpur, Gazipur, Bangladesh

${ }^{2}$ Department of Soil Science, Bangabandhu Sheikh Mujibur Rahman Agricultural University, Gazipur-1706, Bangladesh *Corresponding author

\begin{tabular}{l|l}
\hline A R T I C L E I N F O & A B S T R A C T \\
\hline $\begin{array}{l}\text { Research Article } \\
\text { Received : 31/08/2020 }\end{array}$ & $\begin{array}{l}\text { To meet the demand for an appropriate soaking duration and priming type, there is a need to } \\
\text { embrace cheap, fast, natural, accessible, and adaptable physiological techniques as soaking of seeds } \\
\text { in water and fresh cow milk. Fresh cow milk contains hormones that relieve seeds from photo, } \\
\text { thermo, physiological and mechanical dormancy. In light of this, this study was conducted to assess } \\
\text { the effect of hydration and fresh cow milk on different seed quality attributes like germination } \\
\text { percentage, mean germination time, the uncertainty of germination process, and synchrony of } \\
\text { germination process of bitter gourd seeds. The study involved two factors namely hydropriming } \\
\text { and different concentrations of fresh cow milk (viz. } 60 \%, 80 \% \text { and } 100 \%) \text {, and the other factor was } \\
\text { seed soaking duration with } 4 \text { levels (i. e., } 0,12,18 \text { and } 24 \text { hours). The experiment was conducted } \\
\text { in a Complete Randomized Design (CRD) with three replicates. Results revealed that the percentage } \\
\text { germination value of seeds soaked in all concentrations of fresh cow milk was better than } \\
\text { hydropriming. A significant germination percentage value of } 96 \% \text { and } 93 \% \text { were recorded for seeds } \\
\text { treated for 18 hours in } 80 \% \text { and } 100 \% \text { concentrations of fresh cow milk respectively. Maximum } \\
\text { uncertainty of the germination process and minimum synchrony of germination the process was } \\
\text { recorded in untreated seed. }\end{array}$ \\
$\begin{array}{l}\text { Keywords: } \\
\text { Hydro-priming }\end{array}$ \\
$\begin{array}{l}\text { Bitter gourd } \\
\text { Feed quality } \\
\text { Germination }\end{array}$
\end{tabular}
Germination
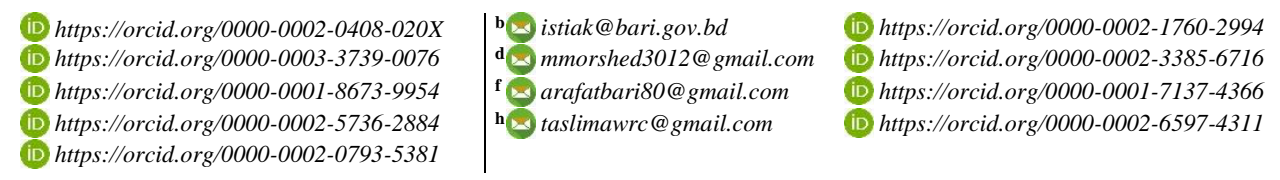

(c) (1) (9) This work is licensed under Creative Commons Attribution 4.0 International License

\section{Introduction}

Bitter gourd (Momordica charantia L.) usually called Karela or balsam pear belongs to family Cucurbitaceae. It is one of the most important summer vegetable crop in Bangladesh. It is a widespread vegetable grown in Asia and other parts of the world. It is usually grown as an annual crop, but it can also perform as a perennial in mild areas and frost-free winters as well. The summer season crop is sown from January to June in the plains (Singh et al., 2006). The optimum temperature of $25-28^{\circ} \mathrm{C}$ is required for the germination of bitter gourd seeds (Peter et al., 1998). Bitter gourd has tremendous economic and dietic importance. Immature fruit is a good source of Vitamin C, and also contains Vitamin A. Bitter gourd is a blood purifier, activates spleen and liver and is highly beneficial in diabetes (Yibchok-Anun et al., 2006). The bitter gourd is very much helpful in curing diabetes. Studies have shown that bitter melon has anti-carcinogenic properties and can be used as a cytotoxic agent against many types of cancer (Grover and Yadav, 2004). Emergence is always a problem in bitter gourd even with the seeds of high germinability due to thick seed coats. To overcome this problem, pre-sowing treatments -soaking or priming of seeds can be practice. Pre-germinated seeds proved superior in the emergence and in stand establishment. The additional advantages of this treatment include, (i) lower seed rate, (ii) dead seeds can be discarded before sowing, and (iii) germinating, but low vigor seeds can be removed before sowing. Recent studies demonstrate speedy germination, early emergence, and vigorous seedlings accomplished by seed soaking in water and milk for a while, followed by surface drying prior to sowing, which may lead to higher crop yield (Harris et al., 2000). This practice of soaking is expressed that seed priming is a simple, inexpensive, and less risk process of improving faster seedling establishment and vigorous early crop growth. Each crop cultivar requires a critical soaking duration and it should be less than the safe limit (Harris et al., 2000). Pre-sowing seed treatments resulted in higher 
germination and earlier seedling emergence, strong growth, early flowering, maturity, and high yields. Speedily germinating seedlings also produce a deep root system and improved seedling establishment in many crops. Seed soaking is a useful to bitter gourd growers under sub-optimal temperature condition for definite successful seedling establishment (Wang et al., 2002; Lin and Sung, 2001). But the literature in Bangladesh in this context is very little. The present research work was conducted in order to study the effect of milk and hydropriming with different soaking duration on the germination and seedling vigor of bitter gourd.

\section{Materials and Methods}

The experiment was laid out at the research laboratory of Seed Technology Division, BARI, Joydebpur, Gazipur, Bangladesh during 2019-2020 in a two factor Complete Randomized Design (CRD) and each treatment was replicated 3 times. The variety of bitter gourd was BARI Korolla-1.

Factor A: Types of priming i.e. hydropriming, and priming with $60 \%$ fresh milk, priming with $80 \%$ fresh milk and priming with $100 \%$ fresh milk of cow.

Factor B: Soaking duration with four levels i.e. 0 h, 12 $\mathrm{h}, 18 \mathrm{~h}$, and $24 \mathrm{~h}$.

Data were recorded considering the following parameters:

- Germination percentage

- Mean germination time

- Uncertainty of the germination process

- Synchrony of the germination process

- Initial seed weight and seed weight after treatment

- Amount of water absorbed at different treatment

Seed germination was conducted using sand media at room temperature $\left(25^{\circ} \mathrm{C}\right)$. Seeds were soaked in water and $60 \%, 80 \%$ and $100 \%$ fresh milk for $12 \mathrm{~h}, 18 \mathrm{~h}$ and $24 \mathrm{~h}$. Initial weight of seed was measured and weight was taken after $12 \mathrm{~h}, 18 \mathrm{~h}$, and $24 \mathrm{~h}$ soaking. The difference between initial weight and weight after soaking for $12 \mathrm{~h}, 18 \mathrm{~h}$, and $24 \mathrm{~h}$ provides the amount of absorbed water.

Twenty-five seeds with three replications were used and expressed in percentage. Then the percentage data were transformed in an Arcsine Transformation.

The mechanics of data transformation are greatly facilitated by using a table of the arc sine transformation. The value of $0 \%$ was substituted by $(1 / 4 n)$ and the value of $100 \%$ by $(100-1 / 4 n)$, where is the number of units upon which the percentage data was based.

The arcsine transformations were used because the percentage of data ranged from 0 to $100 \%$. Before the transformation, all zero values are replaced by [1/4(25)] and all 100 values by $(100-[1 / 4(25)]\}$. The transformed data are shown (following the procedure of Chapter 2, Section 2.1.2- Statistical Procedure of Agricultural Research) is in Table 1. For comparisons of all possible pairs of means, the values were first applied to the transformed means and then transferred to the original means.

Mean germination time was calculated by the Equation 1:

$$
\overline{\mathrm{t}}=\frac{\sum_{\mathrm{i}=1}^{\mathrm{k}} \mathrm{n}_{\mathrm{i}} \mathrm{t}_{\mathrm{i}}}{\sum_{\mathrm{i}=1}^{\mathrm{k}} \mathrm{n}_{\mathrm{i}}}
$$

Where, $t_{i}$ : time from the start of the experiment to the $i$ th observation (day for the example); $n_{i}$ : number of seeds germinated in the $i$ th time (not the accumulated number, but the number correspondent to the $i$ th observation), and $k$ : last time of germination (Labouriau and Valadares, 1976; Labouriau, 1983; Ranal and Santana, 2006).Uncertainty of the germination process was calculated by the expression:

$$
U=-\sum_{i=1}^{k} f_{i} \log _{2} f_{i} \text {, being } f_{i}=\frac{n_{i}}{\sum_{i=1}^{k} n_{i}}
$$

Where, $n_{i}$ : number of seeds germinated in the $i^{t h}$ time and $k$ : last time of germination (Labouriau and Valadares, 1976; Labouriau, 1983).

Synchrony of germination was calculated by the expression:

$$
\mathrm{Z}=\frac{\sum_{\mathrm{i}=1}^{\mathrm{k}} \mathrm{C}_{\mathrm{n}_{\mathrm{i}}, 2}}{\mathrm{C}_{\sum \mathrm{n}_{\mathrm{i}}, 2}} \text {, being } \mathrm{C}_{\mathrm{n}_{\mathrm{i}}, 2}=\mathrm{n}_{\mathrm{i}}\left(\mathrm{n}_{\mathrm{i}}-1\right) / 2
$$

Where, $C_{n_{i}, 2}$ :combination of the seeds germinated in the $i^{\text {th }}$ time, two by two; $n_{i}$ : number of seeds germinated in the $i^{\text {th }}$ time (Labouriau and Valadares, 1976; Labouriau, 1983).

\section{Data Analysis}

The data collected on the effect of soaking duration and types of priming on germination and related parameters were subjected to two-way analysis of variance (ANOVA) using open-source R software. Separation of significant means was carried out using the Least Significant Difference (LSD). All percent of germination data were arcsine percentage transformation prior to analyses because it is appropriate for the percentage of data covering a wide range (Akindele, 2004; Gomez and Gomez, 2010; Sananse and Maidapwad, 2014).

\section{Results and Discussion}

The germination capacity of one seed, based on a binary answer (germinated/non germinated), is one qualitative attribute of the germination process generally converted in a quantitative attribute, commonly in percentage. The results of (Table 1) showed that there are significant differences (at $5 \%$ level) between effective treatments on germination characteristics and the different treatments resulted in significant differences among germination properties.

The results of this research showed that the germination percentage of Momordica charantia increased due to the application of priming in different duration and concentrations. According to the obtained results, treatment for $80 \%$ milk with $18 \mathrm{~h}$ soaking duration was the most effective treatments for improvement of seed germination $(96 \%)$ which was statistically identical with $100 \%$ and $60 \%$ milk with $18 \mathrm{~h}$ soaking duration. This technique can be as a seed treatment that can increase rate, percentage, and uniformity of germination or seedling emergence. Results for zero hours $(0 \mathrm{~h})$ soaking duration for $60 \%, 80 \%$, and $100 \%$ milk reflect not having any combination of this treatment. In all cases of interaction 
effects germination percentage for untreated seeds were minimum $(66.33 \%)$.

Considering individual and combine effect, germination percentage has increased with soaking duration up to 18 hours, and then it starts declining. Results reveal that soaking duration and priming types have a great influence on germination for the seeds having thick seed coats. Milk has considered better priming agent than that of water.

Fresh cow milk had $0.012 \mu \mathrm{g} \mathrm{mL}^{-1}$ and $0.006 \mu \mathrm{g} \mathrm{mL}^{-1}$ for IAA and ABA, respectively. The excellent performance of fresh cow milk in breaking the dormancy in $M$. charantia seeds could be attributed to the presence of hormones such as Indole Acetic Acid (IAA) and Abscisic acid (ABA) (Adelani and Maisamari, 2016). Cow milk (organic or otherwise) has been shown to contain 35 different hormones and 11 growth factors (Djamgoz and Jane, 2015). Hormones are known to speed up the rate of germination of plant seeds. Major plant growth regulators (PGRs) significantly enhanced seed germination rate in black gram and horse gram (Chauhan et al., 2009), floral buds in Jojoba (Prat et al., 2008) and other growth parameters in different plants. Growth regulators are organic substances besides nutrients, synthesized in plants, causing an alteration in their cellular metabolism (Rastogi et al., 2013).

Considering the interactive effect of soaking duration and fresh cow milk on mean germination time (Table 2), the lowest mean germination time was recorded in hydration for 24 hours (6.667) and the highest was recorded in untreated seed (8.471). In all cases mean germination time has reduced with increasing of soaking duration except for priming with $100 \%$ milk. This expression would have a direct interpretation on the sense that low values of mean germination time would be associated with concentrated germination in time.

From Table 2, maximum (2.890) value for the uncertainty of germination process was recorded in untreated seeds and the minimum (1.925) was recorded in $80 \%$ milk for $18 \mathrm{~h}$ soaking duration. Considering all values (except for $100 \%$ milk), it has been evidenced that soaking duration has a great effect on the uncertainty of the germination process then it comes to consider types of priming. The value for priming with $100 \%$ milk and $24 \mathrm{~h}$ soaking duration $(2.823)$ is almost near to the value of the untreated seed.

Table 1. Interaction effect of soaking duration and type of priming on germination of $M$. charantia seeds

\begin{tabular}{l|cccccccc}
\hline \multirow{3}{*}{ SD } & \multicolumn{7}{|c}{ Types of priming } \\
\cline { 2 - 8 } & \multicolumn{2}{|c}{ Hydro-Priming } & \multicolumn{7}{c}{$60 \%$ Milk } & \multicolumn{2}{c}{$80 \%$ Milk } & \multicolumn{2}{c}{$100 \%$ Milk } \\
\cline { 2 - 9 } & TM & OM & TM & OM & TM & OM & TM & OM \\
\hline $0 \mathrm{~h}$ & $52.74^{\mathrm{g}}$ & $66.33^{\text {gh }}$ & $0.57^{\mathrm{h}}$ & $0.00^{\mathrm{h}}$ & $0.57^{\mathrm{h}}$ & $0.00^{\mathrm{h}}$ & $0.57^{\mathrm{h}}$ & $0.00^{\mathrm{h}}$ \\
$12 \mathrm{~h}$ & $61.98^{\text {def }}$ & $77.87^{\text {def }}$ & $59.88^{\text {efg }}$ & $74.67^{\text {efg }}$ & $62.58^{\text {def }}$ & $78.67^{\text {def }}$ & $59.01^{\text {fg }}$ & $73.33^{\text {fg }}$ \\
$18 \mathrm{~h}$ & $68.77^{\text {bcd }}$ & $86.80^{\text {bcd }}$ & $71.53^{\text {bc }}$ & $89.33^{\text {bc }}$ & $80.48^{\mathrm{a}}$ & $96.00^{\mathrm{a}}$ & $75.55^{\text {ab }}$ & $93.33^{\text {ab }}$ \\
$24 \mathrm{~h}$ & $62.25^{\text {def }}$ & $78.33^{\text {def }}$ & $64.73^{\text {cdef }}$ & $81.33^{\text {cdef }}$ & $66.34^{\text {cde }}$ & $83.33^{\text {cde }}$ & $59.18^{\text {efg }}$ & $73.00^{\text {efg }}$ \\
\hline CV $(\%)$ & 6.66 & 7.78 & 6.66 & 7.78 & 6.66 & 7.78 & 6.66 & 7.78 \\
\hline
\end{tabular}

*SD-Soaking duration, TM: Transformed Mean, OM: Original Mean

Table 2. Interactive effect of soaking duration and types of priming on mean germination time, uncertainty of germination process and synchrony of germination process

\begin{tabular}{|c|c|c|c|c|}
\hline Soaking duration & \multicolumn{4}{|c|}{ Types of priming } \\
\hline \multicolumn{5}{|c|}{ Mean Germination Time } \\
\hline & Hydration & $60 \%$ Milk & $80 \%$ Milk & 100\% Milk \\
\hline $\mathrm{Oh}$ & 8.471 & - & - & - \\
\hline $12 \mathrm{~h}$ & 7.947 & 7.941 & 7.933 & 8.053 \\
\hline $18 \mathrm{~h}$ & 7.905 & 7.625 & 7.609 & 7.458 \\
\hline $24 \mathrm{~h}$ & 6.667 & 7.333 & 7.176 & 7.875 \\
\hline $\mathrm{CV}(\%)$ & 6.45 & & & \\
\hline LSD & 0.67 & & & \\
\hline \multicolumn{5}{|c|}{ Uncertainty of germination process } \\
\hline $0 \mathrm{~h}$ & 2.890 & - & - & - \\
\hline $12 \mathrm{~h}$ & 2.629 & 2.631 & 2.826 & 2.580 \\
\hline $18 \mathrm{~h}$ & 2.343 & 2.049 & 1.925 & 2.689 \\
\hline $24 \mathrm{~h}$ & 2.698 & 2.398 & 2.593 & 2.823 \\
\hline $\mathrm{CV}(\%)$ & 9.39 & & & \\
\hline LSD & 0.67 & & & \\
\hline \multicolumn{5}{|c|}{ Synchrony of germination process } \\
\hline $\mathrm{Oh}$ & 0.095 & - & - & - \\
\hline $12 \mathrm{~h}$ & 0.129 & 0.125 & 0.105 & 0.110 \\
\hline $18 \mathrm{~h}$ & 0.133 & 0.167 & 0.272 & 0.233 \\
\hline $24 \mathrm{~h}$ & 0.152 & 0.152 & 0.150 & 0.174 \\
\hline $\mathrm{CV}(\%)$ & 1.85 & & & \\
\hline LSD & - & & & \\
\hline
\end{tabular}




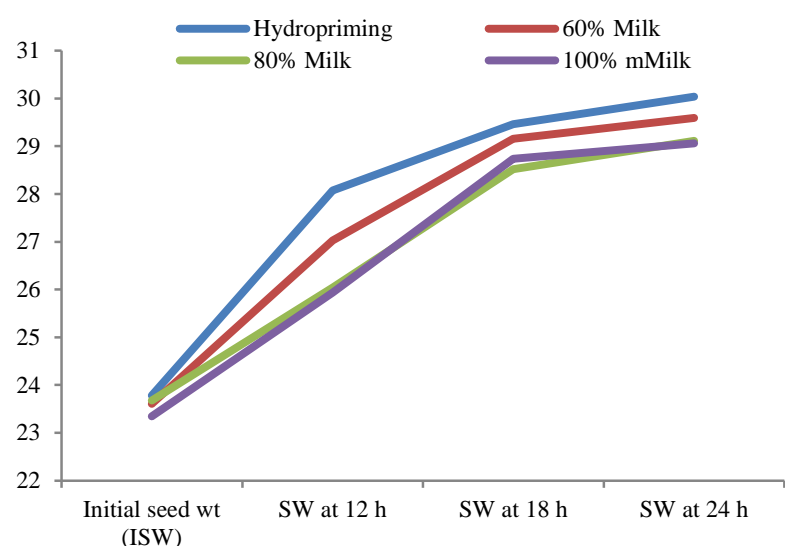

Figure1. Variation of seed weight at different soaking duration and types of priming

From Table 2, maximum (2.272) value for synchronization of the germination process was recorded in $80 \%$ milk for $18 \mathrm{~h}$ soaking duration and the minimum (0.095) was recorded in untreated seeds. In all cases except hydration, the value for synchronization of the germination process has increased up to 18 hours soaking duration and then it declined. In the case of hydration, all values were increased with time.

Short intervals between two consecutive evaluations make the determination of mean germination time more accurate. It means that the mean germination time and synchrony are estimated using high intervals between observations (Dorneles et al., 2005).

It is possible to quantify the characteristic of synchronization of germination process by means of a measurement named synchrony of the germination process, uncertainty associated with the distribution of the relative frequency of germination (U), or informational entropy. Another important point is related to the interval between two consecutive evaluations. Depending on this interval, seeds could be considered as synchronized and homogeneous.

The result (Figure 1) showed that maximum seed weight (28.07 g, $29.46 \mathrm{~g}$ and, $30.04 \mathrm{~g}$ respectively) was found when the seeds were soaked in water in all three cases of soaking duration (12 h, $18 \mathrm{~h}$ and $24 \mathrm{~h}$ ) ie., maximum absorption of water has occurred in that case and the minimum was recorded when the seeds were soaked in $100 \%$ milk. The water absorption rate was almost similar in priming with $80 \%$ milk and $100 \%$ milk. It has also revealed that only water abruption does not effect on seed germination process though $80 \%$ milk provide maximum seed germination.

The rate of absorbing water from $0 \mathrm{~h}$ to $12 \mathrm{~h}$ was very high in hydro-priming and in soaking with $60 \%$ milk and then it declined, but in the case of $80 \%$ milk and $100 \%$ milk water absorption rate was maximum from $12 \mathrm{~h}$ to $18 \mathrm{~h}$ and then it declined (Figure 2).

\section{Conclusion}

Choosing the measurements and the interval of evaluations, according to the objective, it can be suggested that priming with $80 \%$ milk for 18 hours is mostly preferable for seed germination and related quality of bitter gourd seed.

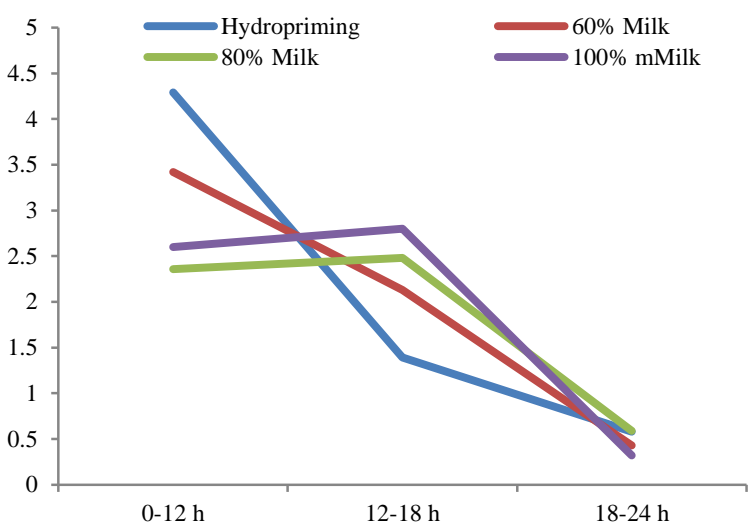

Figure 2. Amount of water absorbed at different Soaking duration and types of priming

\section{References}

Adelani DO, Maisamari IJ. 2016. Effect of fresh cow milk and coconut milk on the germination of baobab (Adansonia digitata) seeds. Biological and Environmental Sciences Journal for the Tropics, 8(4): 7-16.

Akindele SO. 2004. Basic Experimental Designs in Agricultural Research. Printed by Royal Bird Venture, Mushin, Lagos, Nigeria, pp. 190.

Chauhan JS, Tomar YK, Singh NI, Seema A, Debarati (2009). Effect of growth hormones on seed germination and seedling growth of black gram and horse gram. Journal of American Science, 5(5): 79- 84 .

Djamgoz M, Jane P. 2015. 10-Step Plan to Help You Overcome and Prevent Cancer'. Vermilion Publisher, 9 p.

Dorneles MC, Ranal MA, Santana DG. 2005. Germinação de diásporos de Myracrodruon urundeuva Allemão (Anacardiaceae) ocorrente no cerrado do Brasil Central. Revista Brasileira de Botânica, 28: 399-408.

Gomez KA, Gomez, AA. 2010. Statistical Procedures for Agricultural Research. Second Edition. John Wiley and Sons, New York, United States of America, p. 680.

Grover JK, Yadav SP. 2004. Pharmacological actions and potential uses of Momordica charantia: A review. J. Ethnopharmacol. 93: 123-132.

Harris D, Tripathi RS, Joshi A. 2000. On-farm seed priming to improve crop establishment and yield in dry direct-seeded rice. Paper presented at the workshop on dry seeded rice Technology, Bangkok, Thailand.

Labouriau LG. 1983. Uma nova linha de pesquisanafisiologia da germinação das sementes. Anais do XXXIV CongressoNacional de Botânica. SBB, Porto Alegre, 11-50.

Labouriau LG, Valadares, MEB. 1976. On the germination of seeds of Calotropis procera (Ait.) Ait. F. Anais da Academia Brasileira de Ciências 48.

Lin JM, Sung JM. 2001. Pre-sowing treatments for improving emergence of bitter gourd seedlings under optimal and suboptimal temperatures. Seed Sci. Technol., 29: 39-50.

Peter KV, Sadhu MK, Raj M, Prasanna KP. 1998. Improvement and cultivation of bitter gourd, snake gourd, pointed gourd and ivy gourd. In: Nayar, N. M., More, A. (Eds.), Cucurbits. Sci. Publishers Inc., Enfield, NH, USA, pp. 187-195.

Prat L, Batti C, Fichet T. 2008. Effect of plant growth regulators on floral differentiation and seed production in jojoba (Simmondsia chinesis (Link) Schneider). Industrial Crops and Products, 27: 44-49.

Ranal MA, Santana DG. 2006. How and why to measure the germination process? Brazilian Journal of Botany, 29: 1-11. doi:10.1590/s0100-84042006000100002 
Rastogi A, Siddiqui A, Mishra BK, Srivastava M, Pandey R, Misra P, Singh M, Shukla S. 2013. Effect of auxin and gibberellic acid on growth and yield components of linseed (Linum usitatissimum L.). Crop Breeding and Applied Biotechnology, 13(2): 1-10.

Sananse, SL, Maidapwad SL. 2014. On analysis of two-way ANOVA using data transformation techniques. International Journal of Scientific Research, 3(11): 480-483.

Singh NP, Singh DK, Singh YK, Kumar V. 2006. Vegetables Seed Production Technology. 1st Ed. International Book Distributing Co., Lucknow. pp. 143-145.
Wang HY, Chen CL, Sung JM. 2002. Both warm water soaking and solid priming treatments enhance anti-oxidation of bitter gourd seeds germinated at sub-optimal temperature. Seed Sci. Technol., 31: 47-56.

Yibchok AS, Adisakwattana S, Yao CY, Sangvanich P, Roengsumran S, Hsu WH. 2006. Slow acting protein extract from fruit pulp of Momordica charantia with insulin mimetic activities. Biol. Pharm. Bull., 29: 1126-1131. 